Volume 6, Issue 1 (2017) 49-68 | Published online 18 October 2017

The publication of the JEOD is supported by the Autonomous Province of Trento, Italy

\section{Linking Social}

and Ecological Sustainability:

An Analysis of Livelihoods

and the Changing Natural

Resources in the Middle

Zambezi Biosphere Reserve

\section{AUTHOR}

\section{ALEXIO MBEREKO}

University of KwaZulu-Natal, College of Health Sciences, School of Nursing \& Public Health

George Campbell Building Howard College, Durban (South Africa) ambereko@gmail.com

\section{OLGA LAIZA KUPIKA}

Chinhoyi University of Technology, School of Wildlife,

Ecology and Conservation (Zimbabwe)

olgal.kupika@gmail.com

\section{EDSON GANDIWA}

Chinhoyi University of Technology, School of Wildlife,

Ecology and Conservation (Zimbabwe)

egandiwa@gmail.com

\title{
ABSTRACT
}

In this paper, we aim to explore community livelihoods and conservation issues surrounding natural resources that are utilised by resettled farmers within the Middle Zambezi Biosphere Reserve, Zimbabwe. Data collection was done in two phases. During the first phase undertaken in 2011, we administered household interviews, held focus group discussions (FGDs) and conducted in-depth interviews. The second phase, conducted in 2015, used FGDs and key informant interviews to gather data on changes in livelihoods and natural resources. Findings indicated limited options of social, human and financial capital. However, diverse livelihoods strategies are pursued in order to minimize the risk of biodiversity degradation. Structural factors that can contribute to cause biodiversity degradation include the failure of the CAMPFIRE Programme; natural resources governance flaws; contests over space and power, and weak policing by institutions devoted to the protection of natural resources. In conclusion, the authors observe how the institutions involved in the management of the protected natural area fail to promote the participation of the local community in the decision-making processes, thus limiting the potential benefits of the designation of the Middle Zambezi Biosphere Reserve.

\section{KEY-WORDS}

BIOSPHERE RESERVE; SOCIAL CAPITAL; HUMAN-WILDLIFE CONFLICT; LIVELIHOODS; PARTICIPATION; SOCIAL ENTERPRISE

\section{Acknowledgments}

The authors are grateful to the farmers of the communities targeted by the study for their participation in the household surveys and focus group discussions. We are grateful to the anonymous reviewers and the editorial team (Colin Campbell, Silvia Sacchetti, Barbara Franchini and Michela Angeli). This research is supported by funding from HEARD and the Department for International Development (DfID) under the Climate Impact Research Capacity and Leadership Enhancement (CIRCLE) programme. 


\section{Introduction}

International policy guidelines on sustainable development advocate for a "win-win" situation in the dialectical relationship between the natural environment and human-economic systems that determine livelihoods (Salafsky and Wollenberg, 2000; Roe and Elliott, 2006; Pahl-Wostl, 2007). The interdependence of society and natural systems complicates the sustainable development agenda in Africa (Pahl-Wostl, 2007; Guerry et al., 2015), especially in the context of deteriorating ecosystem services. Sustainable development scholars are increasingly realising the impotency of the socialenvironmental nexus because of the difficulties in establishing stable markets in developing countries (Roe and Elliott, 2006; Pahl-Wostl, 2007). Sustainable development has been conceptualised by scholars as having three pillars, which are (i) the natural environment (biodiversity), (ii) the social dimension and (iii) the economic dimension (Lehtonen, 2004). The need to promote solutions to reconcile the conservation of biodiversity with the sustainable use of natural resources necessitated the implementation of the United Nations Educational, Scientific and Cultural Organization (UNESCO) Man and Biosphere (MAB) Programme (Ishwaran, Persic, and Tri, 2008). Biosphere reserves have potential to promote biodiversity conservation and socio-economic development.

Each biosphere reserve is intended to fulfil complementary and mutually reinforcing functions related to the conservation of landscapes, ecosystems, species and genetic variation; fostering socioculturally and ecologically sustainable economic and human development and providing support for research, monitoring, education and information exchange related to local, national and global issues of conservation and development. The UNESCO MAB Programme overarching objective is to provide an effective contribution towards the implementation of the Post-2015 Development Agenda and the Sustainable Development Goals and related targets (Batisse, 1997). To achieve this, one of the strategic goals of the UNESCO MAB Programme is to "enhance the conservation and sustainable use of biodiversity, ecosystem services and natural resources" (Batisse, 1997). To this end, UNESCO biosphere reserves (BRs) are viewed as places to promote climate change resilience and mitigation by dealing with the trade-offs at the social-environment interface (Batisse, 1997; Schliep, et al., 2008).

This study draws on the case of the Middle Zambezi BR to interrogate the concept of sustainable development at the conservation and human nexus. Communities that inhabit within the buffer and transitional zones of biosphere reserves are important in the understanding of human-environmental interactions, since they occupy marginal areas (Taylor, 2010). Besides public rhetoric discourses, Zimbabwe seem to have not made much progress in changing from the protectorate towards community participation approach, yet these communities indirectly pay for the cost of wild animals in their spaces (Le Bel, La Grange and Czudek, 2016). The Middle Zambezi is the only BR in the country, and it shares boundary spaces with poor subsistent farmers who mainly depend on natural resources and the livelihoods capitals, in the context of weak institutional support (Mbereko, Scott, and Kupika, 2015). The study sought to analyse the temporal livelihoods dynamics and the conservation issues of natural resources that are utilised by resettled farmers bordering the Middle Zambezi BR. 
Since the Second World War, scholars as well as governments and non-governmental organisations have been grappling with the desire to conserve biodiversity, improve human livelihoods and promote economic growth. Development strategies in these three dimensions were pursued separately, but scholars and policy makers prioritised biodiversity more than the other two (Lehtonen, 2004). In 1987, the Brundtland Commission ${ }^{1}$ popularised and defined the discourse of sustainable development (Scoones, 2015). The definition captured the ecological, economic and social dimensions of development. Since then, many scholars have defined the concept of sustainable development in different terms, but maintaining the three pillars approach. However, it is important to note that in practice geographers and other scientists applied the concept with a bias towards environmental protection (Lehtonen, 2004). The demise of communist Russia created opportunities to promote shifts from populist politics and socialist economics in the developing countries to democratic and neoliberal institutions. Scholars have identified power contestations amongst stakeholders associated with social enterprises in biosphere reserves and these include the state, non-governmental organizations, hunters, tour operators and local communities (Batisse, 1997; Jones, 2005; Kimbu, 2013). Most African countries still have centralized institutional structures, despite several studies demonstrates how decentralized structures enable stakeholder participation and are more efficient in promoting sustainable development (Kimbu, 2013). Different stakeholders hold different levels of power, and literature show that such power can be used to exclude poor communities (Jones, 2005, Kimbu, 2013; Mbereko, Scott and Kupika, 2015).

Structural and climate changes affect sustainable livelihoods and ecosystems. Sustainability is intended as the maintenance or increase of the total stock of different types of capitals (Lehtonen, 2004). Thus, access to natural and economic resources facilitates the production of sustainable livelihoods. Livelihoods are understood in the confines of five capitals which are physical, financial, social, natural and human (Salafsky and Wollenberg, 2000). Livelihoods are said to be sustainable when they can cope with, and recover from stresses and shocks, maintain or enhance its capabilities and assets, while not undermining the natural resource base (Scoones, 1998). In rural Sub-Saharan Africa, scholars have demonstrated that climate change is impacting negatively on natural resources, which human populations rely on as the bases of their livelihoods (Salafsky and Wollenberg, 2000; Scoones, 2015). The livelihoods framework has been successfully used to understand and promote rural development (Chambers, 2011). The livelihoods framework is therefore applied in this study to understand changing natural resources and emerging livelihoods strategies. Recent literature demonstrates that rural communities are diversifying from consumptive natural resources based livelihoods strategies in order to cope with perturbations resulting from climate and structural changes. The development of new markets in Sub-Saharan Africa necessitates that people invest and respond to demand by supplying the needed commodities (Kimbu, 2016). We merged the livelihoods framework with the social enterprise approach to interrogate the new enterprises that mediate current human-

Fromally known as the United Nations World Commission on Environment and Development (WCED). 
environmental interactions in BRs. The adoption of social enterprise approach allows for the analysis of livelihoods from a more diverse innovative lens (Sacchetti and Campbell, 2014).

According to Sacchetti and Campbell (2014), social enterprises can be defined as value-based businesses set up for social and/or environmental purposes, driven by an entrepreneurial spirit. Social enterprise approach promotes innovations that turns community units into viable economic enterprises by diversifying from an agricultural economy to the provision of goods and services (ibid.). From the 1990s to present, beneficiary relationship between people and protected areas are increasingly being promoted (Batisse, 1997). BRs world-wide are promoting community entrepreneurship especially in the field of tourism and commodity trading that allow for human benefits while conserving natural resources (Ogutu, 2002; Rao et al., 2003; Naughton-Treves, Holland and Brandon, 2005; Edge and McAllister, 2009). Nevertheless, entrepreneurial initiatives on BRs present some critical aspects. For example, tourism do not necessarily guarantee economic, social and ecological viability and development (Johnson, 2010). However, initiatives where communities have been integrated as key stakeholders in the conservation of fauna and flora in protected game areas proved to be successful. Evidence suggests that when communities effectively participate and realise economic benefits from wildlife, conservation efforts are aided (Getz et al., 1999; Jones and Weaver, 2009; Ostrom, 2015). Scholars as Jones and Weaver (2009), Le Bel, La Grange and Czudek (2016) have documented social enterprise initiatives that promoted community and ecological development in differing extents, such as community participation in ecotourism activities and programmes such as the Community Based Natural Resources Management (CBNRM) and the Community Areas Management Programme for Indigenous Resources (CAMPFIRE).

Social enterprise scholars argue that social and human capitals are necessary to allow collective conservation action and equitable benefits sharing in communities (Sacchetti and Campbell, 2014; Ostrom, 2015) as well as for communities to benefit sustainably from biodiversity conservation (Pretty and Ward, 2001; Jones, 2005). Social capital refers to the networks of social relations characterised by norms of trust and reciprocity that can improve the efficiency of society by facilitating coordinated actions (Lehtonen, 2004; Jones, 2005). Social capital components are participation, social networking, trust, reciprocity and vertical and horizontal associations amongst actors (Jones, 2005). Thus, social capital is part of the power relations within a society system and embedded within its cultural and political context.

Out of the components of social capital, social enterprise scholars have mainly debated on the theoretical and practical application of "participation". Scholars have argued that outsiders rather than the communities themselves are promoting social enterprises initiatives (Jones, 2005). Participation is dominantly understood from two overlapping schools of thought. Firstly, it is a means to increase efficiency, the argument being that if people are involved they are more likely to agree with and support a new process or service (Pretty, 1995). Secondly, participation is a fundamental right, as it initiates mobilisation for collective action empowering and building institutions (Pretty, 1995). Both definitions associate participation with increased mobilisation of stakeholders' ownership of policies and projects for greater efficiency. In tourism, there is a drive to shift away from a predominance 
of ownership and control of rural and isolated area by tourism operations promoted by western capitalist organizations to community based operators (Wearing and McDonald, 2002). Wearing and McDonald (2002) argue that rural tourism sites are places where "new meanings" are produced within the confine of the dominant western discourse. For sustainable livelihoods and ecosystems to be a reality, there is need for the creation of new meanings about rural people and the tourism/conservation industry in biospheres in order to promote effective local communities' participation in the market.

\section{Study background}

Since the establishment of the first national park in $1872^{2}$, the world system of protected areas has grown exponentially, particularly in developing countries, where biodiversity is greatest (McNeely, 1994; Naughton-Treves, Holland and Brandon, 2005). In Zimbabwe, the first protected game park was Hwange National Park followed by the mid-Zambezi parks, which were established in 1929 and 1963 respectively. Protected game areas are effective in preventing destruction and protecting ecosystems within their borders. It should be recalled here that game parks protect biodiversity through displacement and exclusion of mainly indigenous people through rigorous laws and fences. In the mid-Zambezi, with the demise of colonialism and its structures, human populations have resettled close to the park boundaries, on marginal lands (Mbereko et al., 2015). Research demonstrates that fauna and flora that is not enclosed in the protected areas is being degraded at a fast pace (Naughton-Treves, Holland and Brandon, 2005). Worse, with declining environmental services ${ }^{3}$, people have been documented to encroach onto the national parks spaces (Timko and Innes, 2009). The protectorate approach results in rich and poor ecological regions across the fence. With the shift in sustainable development discourse, neo-liberal policies gave room to social and environmental benefits from social enterprise initiatives. The BR initiative by UNESCO is one of the programs instituted to benefit communities and the environment.

BRs were created under the UNESCO Man and Biosphere (MAB) Programme in 1971, with an aim of reconciling local communities' socio-economic development with the conservation of biodiversity. BRs are conservation sites established by countries and recognised under the UNESCO MAB Programme to promote sustainable development in areas where wildlife and humans coexist (PoolStanvliet and Clusener-Godt, 2013). The World Network of Biosphere Reserves (WNBR) currently counts 669 sites in 120 countries all over the world. Sub-Saharan Africa has 64 BRs in 28 countries (Pool-Stanvlie and Clusener-Godt, 2013). The biosphere approach advocates for human participation in, and livelihoods benefit from game parks and sustainable ecological conservation (Stoll-Kleemann, De la Vega-Leinert, and Schultz, 2010). Lessons learnt from established BRs caution on the need to moderate

\footnotetext{
2 In 1872, Yellowstone Park in the United States of America was established as the first national park in the world.

3 Environmental services are intended as the benefits derived from biodiversity which include: improved soil fertility and food security, facilitate access to clean water, fishing, hunting for meat, medicinal products, energy, combat desertification. They contribute to creating "green jobs" and bolstering economic growth and livelihoods.
} 
the capacity of these reserves to alleviate poverty (Batisse, 1997). Moreover, the process of participatory conservation carries new dangers for effective BR management, when the aspirations of communities and other stakeholders do not "fit" with a predetermined interpretation of sustainable development (Stoll-Kleemann, De la Vega-Leinert, and Schultz, 2010). On this topic, it should be considered that socio-economic research conducted so far on the Middle Zambezi BR is very limited.

The Middle Zambezi is the only BR in the country and it was created on 5 June 2010. According to the authors of his paper, research on the Middle Zambezi BR is biased towards natural sciences (with studies focusing on genetics, ecology and effects of climate change on wildlife), yet there is limited social science research on aspects such as livelihoods, participation and beneficiation. Yet, in order to accomplish the win-win situation as set out by the 2030 Agenda for Sustainable Development, the interaction of humans and the natural environment needs to be understood from the natural and socio-economic perspectives. We contend that there is a need for further socioecological research to investigate the human livelihoods' and natural resources utilisation in the wider political economy and climate change context.

\section{Research methodology}

\subsection{Study area}

The study was conducted in Nyamakate, a resettlement area in the Hurungwe district, which is one of the six districts in the Mashonaland province in Zimbabwe. The Nyamakate resettlement was created in the early 1980s, by people who settled on unoccupied state land (Mbereko et al., 2015). Nyamakate is located in the northern part of Zimbabwe and shares a boundary on the north with the Hurungwe and Charara safari areas (Figure 1).

A fence known as the "game fence" demarcates the boundary of the BR protected area and the Nyamakate resettlement. Over the time, the fence has been vandalized and physically it does not exist anymore; nevertheless, the local communities know where the boundary line is located. Hurungwe and Charara safari areas are situated within the mid-Zambezi valley and are part of the Middle Zambezi BR. The national parks are well endowed with varied tree and wild game species. The Nyamakate communities occupy a space that was demarcated as a buffer zone due to population pressure and the need for arable land in the context of an enabling policy framework (Mbereko et al., 2015). The Communal Areas Management Programme for Indigenous Resources (CAMPFIRE) ${ }^{4}$ was implemented in the area as a

\footnotetext{
4 In 1980, the Zimbabwean government amended the Parks and Wildlife Act to provide for CAMPFIRE. The programme was implemented in Masoka village, Mahenye village and Nyaminyami District on experimental bases and in the mid-1980s CAMPFIRE was quickly out rolled when the experiment proved to be a success (Hasler, 1999; Frost and Bond, 2008). In Nyamakate the programme has been largely controlled by the rural district council and there are the major beneficiaries (Mbereko et al., 2015).
} 
conservation strategy that incorporated local communities in biodiversity conservation. However, the community are reported not to be benefiting significantly from the CAMPFIRE Programme since the hyperinflation period in 2000s (Mbereko, Scott and Kupika, 2015).

Figure 1. Location of the Nyamakate community in the Middle Zambezi BR

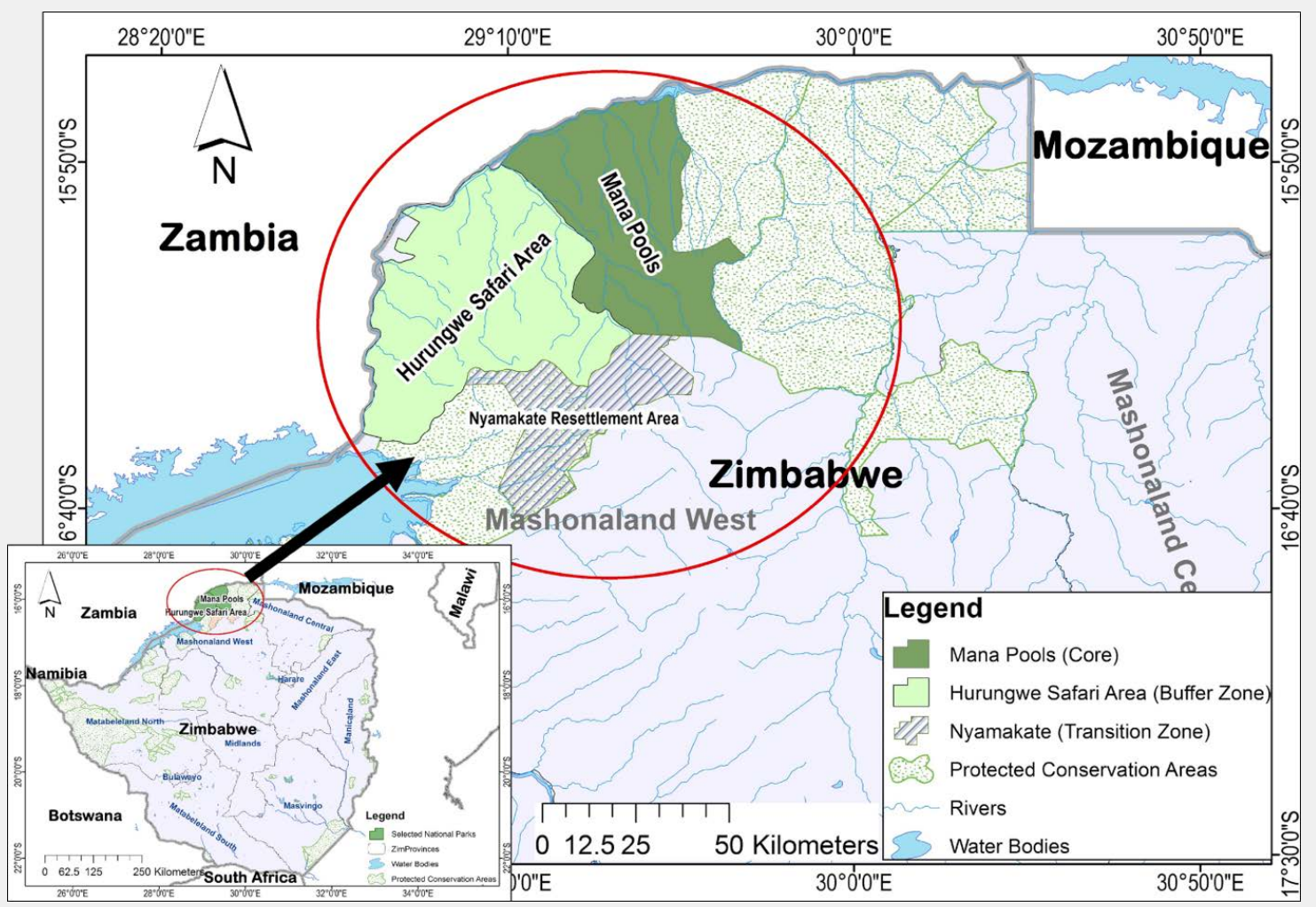

\subsection{Sampling and data collection}

The study adopted a qualitative approach, that was preferred since it explores multiple livelihoods realities and the people's relations within the Middle Zambezi BR. The Nyamakate community was purposively selected to be the study area. Nyamakate satisfied the inclusion criteria which were established as follow: (i) an area in the buffer zone, (ii) an area under the CAMPFIRE, (iii) a rural area, and (iv) an area that had reported cases of human-wildlife interaction. The Nyamakate area has 32 villages that are divided into two main sub-areas, according to two the phases in which the area was resettled. During the first phase (in the 1980s) few households spontaneously occupied the land, while during the second/new phase (in the 1990s) the resettlement was planned by the government (Mbereko et al., 2015). The government decided to resettle people in the Nyamakate 
area because of the need to reduce population pressure from the Hurungwe area and because the Nyamakate area was under state land scarcely habited (Mbereko et al., 2015). The first phase villages are dominantly in the lowland, while the second/new phase dominantly occupy the mountainous highlands. The demarcation of low and highlands formed clusters for this study and two villages were randomly selected from each cluster. Systematic sampling was used within villages to draw 10 household interview participants. Every fifth household was recruited into the study, however-in the event of the household head being absent or unwilling to be interviewed - the next household was considered. Except for one interview where permission to record was declined, the rest were recorded using a Dictaphone.

Data collection was done in two phases. In the first phase in 2011, we administered household interviews, held focus group discussions (FDGs) and conducted in-depth interviews. Follow up data collection was done in 2015. The second phase used FGDs and interviews to gather data on changes in livelihoods and the natural resources.

\subsection{Data analysis}

Thematic approach was used to interpret qualitative data. Interviews and FGDs transcripts were transcribed verbatim from the native language Shona into English. The transcribed text were entered in a software for qualitative data storage and analysis called NVivo. We adopted Dey's (1993) approach (thematic) in the interpretation of the data following the stipulated five stages: description, contexts, intentions, classification and making connections.

\section{Results}

\subsection{Human and financial capital}

The average age of the 40 household heads interviewed in 2011 was 53 years of age and seventythree percent of them were males. Sixty-five per cent of the 40 households were extended families. The minimum and maximum number of household population was three and 14 respectively and their average age was 24 . The average household population was seven people, while the mean nucleus family size was five people. All the 26 extended families were multi-generational (e.g., a grandmother living with two daughters and five grandchildren). The 40 interviewed household heads had different levels of education. Nine had never attended formal education, 15 had attained primary level education, nine had participated in vocational training courses (in fields such as construction, welding, motor mechanics, etc.), and seven had attained secondary grade level education. FGDs held in 2015 show that people who are formally defined as inactive are forced to work order to survive and cope with the shortage of jobs in the labour market. Wealthier families can hire other villagers (either on permanent or temporary basis) as workforce to be employed 
in the tobacco and maize fields or at their homesteads (e.g. fetching water and firewood). These wealthier families prefer hiring family units instead of single workers as family units are much easier to negotiate with in terms of labour costs and payment modalities. Hired family unites get food and a small salary in exchange for their labour.

The average monthly income for the 40 households was USD 173, and the median was USD 137.50. The maximum income per household per month was USD 800, and the minimum was USD 20. All households considered by the study practiced agriculture as the primary livelihoods activity. It was reported that agriculture primarily gave the households food and excess was sold on to the market. According to interviewee 13, "ifyou do not farm, then what will you eat? All other needs are secondary". There were people who were recognised as "master farmers", these people engage in farming mainly for selling their produce on the market. In 2011, farmers dominantly farmed maize and had made every effort to intensify maize and cotton production for the market. It was reported that some farmers used to farm both maize and cotton in order to reduce the risk associated with rainfall variability and market price surges in the two crops. However, the market price of both crops was considered to be bad by the interviewees. In particular, maize was considered not worthwhile because the prices were low and the Grain Marketing Board ${ }^{5}$ did not promptly make the payments. Cotton was paid cash upon delivery at the auctions, located at the nearest shopping centre.

In 2015, community members reported that their income was declining from the 2011 levels. Agricultural productivity of maize had declined while that of cotton was close to non-existent. Some farmers with work force and financial capital were increasingly turning to cultivation of tobacco. FGD participants indicated that tobacco was fetching good market prices as compared to traditional crops. Those farmers who could not afford tobacco farming resorted mainly to nonagricultural income generating activities. FGD participants reported that people were increasingly relying on remittances from relatives working outside the Nyamakate area instead of agriculture. Other livelihoods sources adopted included trading, prostitution, piecework and employment for the semi-skilled villagers. Widows and single women were reported as being vulnerable and most likely to adopt prostitution/transactional sex as a coping or/and adaptation strategy. Semi-skilled and skilled artisans used their skills to earn an income on the labour market (e.g. in the building and welding sectors). Those who could not earn money in these non-agricultural income generating activities were more inclined to over exploit the forests and wildlife to survive. They would harvest mushroom, honey, game poaching ${ }^{6}$ and cut down trees for sell on the Chirundu-Harare highway.

\footnotetext{
The country's leading grain trade and Marketing Company was established under the Maize Control Act of 1931. Its basic responsibilities were to accord producers their fair share of the local and export markets, to provide them with a guaranteed outlet for their excess controlled products and to ensure the availability of adequate supplies for the local demand either from internal production or from exports (see the official website: www.gmbdura.com).
}

6 This term refers to the hunting or capturing of wild animals that is considered illegal. 


\subsection{Social capital}

The kinship ties informed the early settlers' sharing and networking arrangements. It was reported that during the first settlement phase it was easier to relate, since there were fewer families as compared to the second phase. In times of droughts and other problems, people would help one another without necessarily repaying. It was reported that people used to help each other with drought power, kitchen utensils, cultivation, food, with care for the ill persons and economic resources to cover funerals costs. The community used to have great respect for the ancestors and the traditional leaders, and elders in the family lineages used to participate in the administration of the area. Norms that promoted sharing and community networks were promoted.

The situation changed after the second settlement phase, promoted by the government (therefore considered as legal). FGD participants reported that the second group of resettled families were from diverse ethnic and cultural groups such as Korekore, Ndau, Vitori, Nyanja, Manyika, Chewa, etc. The sharing arrangements were limited to neighbours and people who share the same totem. Moreover, it was reported that in some cases families did not want to share anything with their neighbours for fear of witchcraft and of being discussed in the community. FGD participants said that inter-ethnic marriages were one of the forces that were uniting people. Other factors bonding people included community meetings, communal work, same political party and children friendship. It was noted in FGDs that in general people identified themselves with their native land, with the exception of Matemai people, who identified themselves with Nyamakate.

The community governing structure had had an effect on people's participation and networking. The traditional leadership that governed the area before the second resettlement used to hold several meetings in which information from higher structures was relayed to the people. The people also used to discuss and approve resolutions dealing with community problems. After the second resettlement phase in the Nyamakate area, community meetings became seldom. At village level, people hold community meetings to decide on issues and make recommendations to higher structures; however, it was reported that often their recommendations were ignored and not integrated into development programs that are cascaded to the village. Political patronage to the ruling party was said to be important, since it determined access to food aid and social power. Access to information on aid and development initiatives and participation in decision-making processes at the community level was determined by membership to the ruling political party, rather than on lineage structures. It was reported that in 2011, there was a maize distribution initiative that mainly benefitted the people at the apex of the ruling party. Other community members complained about a seed handout initiative on which the community had not been properly informed.

The low sharing and networking arrangements are reportedly being worsened by hunger, poverty and natural resources scarcity. For instance in the past, farmers with draught power used to lend it to other families without demanding a payment in exchange, trusting that they would have been assisted in their turn in the future, in case of need. More recently, due to the escalation of harvest uncertainty, families with draught power hire it out to their neighbours for money or foodstuff. Moreover, it was reported that frequent droughts and erratic rainfall had forced people to hire out draught power 
and labour in order to reduce the risks associated with crop failure. Although the monetarisation of borrowing arrangements and low-wages impact negatively on poor households, the social networks that are formed become handy in times of risk. It was reported that households are desisting from assisting need household with food because uncertainties of a good harvest in the next season.

\subsection{Natural capital and natural resources change}

Study participants indicated that they benefitted from the different natural resources, such as water, soil, fauna and flora (Table 1). However, access and use of these resource units was determined on their availability and on institutional factors (i.e., law, traditional bestowed property rights and traditional/religious taboos. The study participants draw resource maps to show the changes in human population versus natural resources units. In both phases of the study (2011 and 2015), participants indicated that the Nyamakate area had good clay soils and there no noticeable decrease was observed. However, the study participants were of the opinion that the human population was increasing and that water, forests and wild animal populations were declining (Table 1).

Table 1. Natural resources change, reasons and perceived impacts on livestock

\begin{tabular}{|c|c|c|c|}
\hline $\begin{array}{l}\text { Natural } \\
\text { resource unit }\end{array}$ & $\begin{array}{l}\text { Nature of Natural } \\
\text { Resource change }\end{array}$ & Reason(s) for change & Perceived impacts on livelihoods \\
\hline Soil & No change & & None \\
\hline \multirow[t]{5}{*}{ Water } & \multirow[t]{5}{*}{ Declining } & $\begin{array}{l}\text { Abandoning traditional rain making } \\
\text { practices }\end{array}$ & $\begin{array}{l}\text { Conflicts between traditional religious } \\
\text { followers and other religions. }\end{array}$ \\
\hline & & $\begin{array}{l}\text { Damming of the Rukomeshe river } \\
\text { affected down-stream water quantities }\end{array}$ & Livestock watering reduced \\
\hline & & Climate change & Poor agricultural yields of maize \\
\hline & & Siltation & \multirow{2}{*}{$\begin{array}{l}\text { Loss of access to aquatic natural } \\
\text { resources }\end{array}$} \\
\hline & & Morally unaccepted practices ${ }^{1}$ & \\
\hline \multirow[t]{5}{*}{ Trees } & \multirow[t]{5}{*}{ Declining } & $\begin{array}{l}\text { Abandoning traditional taboos } \\
\text { (Rambotemwa) }\end{array}$ & \multirow[t]{2}{*}{ Loss of important tree species } \\
\hline & & Curing tobacco with firewood & \\
\hline & & Over harvesting & \multirow[t]{2}{*}{ Reduced energy source } \\
\hline & & Make shift roads & \\
\hline & & Population pressure & Disappearing of "mythical fences" \\
\hline \multirow[t]{3}{*}{ Wild animals } & \multirow[t]{3}{*}{ Declining } & Poaching & Availability of cheap game meat \\
\hline & & Avoidance of human populated areas & \multirow{2}{*}{$\begin{array}{l}\text { Reduced destruction of livestock and } \\
\text { crops }\end{array}$} \\
\hline & & Hunting activities in the safari area & \\
\hline
\end{tabular}


Religious, cultural, institutional and natural factors affected water availability and access. It was reported that the rainmakers still exist in the Nyamakate area, but are abandoning their practices because people no longer respect them. According to one of the traditional leaders interviewed, amongst the causes that led to the abandonment of rainmaking ceremonies are the influence of western religions, the election of illegitimate chiefs over the area, and development projects that do not respect sacred sites. FDG participants reported that commercial water users upstream of the Rukomeshe River erected two dams and draw huge amounts of water. The resettled commercial farmers upstream were reported to have influence over the catchment council, which is in charge of water distribution. FGD participants in the Nyamakate area contend that the commercial activities upstream are largely responsible for the drying of the river. It was observed that the Rukomeshi River is seasonally flowing, yet it was reported to be a perennial river in the past. Furthermore, the river was observed to be silted and the water dries quickly after rains. Data from the FGDs and interviews demonstrate that siltation was caused by poor agricultural practices from both the Nyamakate and upstream areas. It was also reported that the shortage of water in the Nyamakate and Rukomeshi rivers makes it difficult for households to access water and aquatic resources (like fish and wild vegetables). Furthermore, there is no water livestock and people resort to watering at the boreholes.

According to the villagers in the Nyamakate area, trees provide a number of functions, which are of fundamental importance for the community. They allow for the crafting of different artefacts such as stools, hoes and axe handles, pounding mills, yokes, etc. Moreover, they provide shade, they host edible caterpillars such as nhowa (Gonimbrasiabelina) harvested on the Mutowa (Diplorhynchus condylocarpon) tree; they provide herbal medicines and building material and are source of energy for domestic use and for the tobacco curing. These forests products are used in processing or production of goods for both domestic use and for the market. Using firewood to curing tobacco was reported as a recent phenomenon with a larger impact to the forests if compared to other uses. The curing process was endangering in particular the mopani (Colophospermum mopane) and mupfuti (Brachystegiaboehmii) tree species that are preferred since they produce higher amounts of heat. All the study participants agreed that trees are declining in the area. A key informant from the Department of Agriculture and Extension Services said, "Deforestation has always been there at a minimal level, but it has increased since many people have started opting for tobacco production. There is a chance that this deforestation may decline as some farmers are now no longer opting to grow it due to reduced market prices". The decline in "mythical fences" resulted in unabated tree harvesting. Headmen, rural district council, the Environmental Management Agency, the Department of National Parks and Wildlife have the power of and police arrest people who cut down trees. However, it was reported that people evade them and continue over harvesting trees.

Human population pressure has contributed to deforestation in the Nyamakate area. It was reported in FGDs that the number of households increased significantly in 1992 due to an influx of

"Mythical fences" derive from local taboos and superstitions associated with sacredness of the environment that help to conserve natural resources (see Mbereko, 2016). 
people under the planned resettlement programme. The number of households per village ranged between 8 and 15 before the 1990s, while in 2015, it ranged between 25 and 40 households. An increase in number of households put pressure on forests. It was reported that the population growth was caused by two main factors. First, the government admitted newcomers into the Nyamakate area. Second, when children became of age and started their own families, land would be allocated in their names. Thus, forests were turned into residential and farming fields. Furthermore, people reported making makeshift roads to access fields, thick forests (were firewood is harvested), villages and other places. It was reported that in the past people settled along the major roads constructed by the council, but since the expansion of Nyamakate no new roads have been constructed.

Community members reported that wild animals' populations has decreased, especially since the mid-1990s to date. Buffaloes (Syncerus caffer), elephants (Loxodonta africana), hippopotamus (Hippopotamus amphibius), lions (Panthera leo), hyenas (Crocuta crocuta) and antelopes (bovidae $s p$.) used to be many in the past. With the increase in human population, poaching also increased. According to the information emerged during FGDs, increased human population in the area created a market for game meat, which was sold at a cheap price. It was also stated that men would arrange themselves into hunting bands and they would target big game like buffaloes. It was also pointed out that wild animals were avoiding areas with high human populations. However, eland, lion and hyena populations were said to be recently increasing between 2011 and 2015. Study participants from the villages close to the game fence blamed the latest increase in lions and hyenas to the hunting activities in the safari area adjacent to the rural communities. An increase in eland sightings particularly during the farming season was attributed to the availability of alternative tobacco crop as an alternative forage from the tobacco fields located within the buffer zone close to the Hurungwe Safari Area. It was also reported that the safari operator placed blocks of salt on water sources close to the game fence in order to attract more wild animals in the safari and increase his business. This mainly lures wild grazers and the carnivores prey on them. This is how lions and hyenas come close to the game fence and escape into the communal areas and consequently preyed on domesticated animals.

\subsection{Institutional issues}

In 2015, 12 institutions operated in the Nyamakate area dealing with natural environment and livelihoods. The institutions ranged from government institutions (i.e., the Agricultural Technical and Extension Services, the Ministry of Health and Child Care, the Department of National Parks and Wildlife Authority, and the Environmental Management Agency); local institutions (i.e., the Hurungwe Rural District Council); local civic organizations (i.e., Carbon Green Africa and related project Kariba REDD+), international NGOs (i.e., World Vision, GOAL, CARE); international organisations (i.e., International Organisation for Migration) and political parties (mainly the Zimbabwe African National Union-Patriotic Front and the Movement for Democratic Change). Government institutions were reported as offering services and implementing central government policies; the Hurungwe Rural District Council (HRDC) was reported to be responsible for 
the governance and administration of the Nyamakate area; the NGOs were reported as mainly providing food relief, care for people living with HIV and Aids and drilling of boreholes; and the politicians were reported as pushing for their political parties interests in gaining legitimacy and/or votes. According to the information reported by the villagers interviewed, politician often enter into conflict with the HRDC and government agencies on natural resources management and development issues. However, politicians at times push for programmes that do not consider the environment or sustainable development. Violent confrontations between politicians and other stakeholders were reported around the CAMPFIRE programme, as well as conflicts between community and HRDC around the hunting concessions.

CAMPFIRE was set up in the late-1980s in the Nyamakate community. The promoters of CAMPFIRE are rural district councils, government institutions as well as community-based and non-governmental organisations (NGOs), the Department of Parks and Wildlife Management Authority and the CAMPFIRE Association (Child, 1993). In an interview with the HRDC official, the CAMPFIRE concept entailed creating a buffer zone around game areas and aimed at harmonising people and wildlife ${ }^{8}$. People were to benefit from natural resources and in turn contribute towards wildlife conservation. Community study participants stated that CAMPFIRE used to be beneficial to the community in the past. For instance, meat resulting from the wild animal control programme (a practice of wildlife resource management for the control of the population of wild animals) was distributed as a compensation to those villagers that had suffered livestock losses or crop destruction. Moreover, any meat remaining after the distribution for compensation was dispensed to other community members ${ }^{9}$. Although-according to the information obtained during an interview with HRDC — the CAMPFIRE programme is still ongoing to the purported benefit of the community; currently the distribution of wild animals' meat has been suspended. The community members therefore perceive that CAMPFIRE programme has collapsed and that currently it does not benefit the inhabitants of the Nyamakate area.

\subsection{Stakeholder conflicts}

\subsubsection{Hunter versus local community}

Community members who participated in the FGD expressed their opposition to the current hunting concession that had been rectified by the HRDC. Contrary to procedure that communities should select the hunter to operate in their safari area, the community members claim that they

\footnotetext{
$8 \quad$ For a detailed explanation of the aims and expected benefits related to the creation of the buffer zone, please see Mbereko et al. (2015).

9 Amongst other benefits that CAMPFIRE provided in the past, the community members mentioned the construction of a school.
} 
had not been consulted when the hunter who is operating in the safari area was granted a license $\mathrm{e}^{10}$. Some alleged that the hunter bribed the HRDC officials to obtain his hunting contract to be extended without full community consultation. One community leader said, "we seat in meetings were we discuss about the hunter's behaviour and being an enemy of the community ... but his contracts are extended. They say he helps conserve wildlife and brings in money". Moreover, it was reported that hunters and clients that kill wild animals in the safari and Nyamakate areas, would sell the meat outside the area (especially to crocodile farms in Kariba) instead of distributing it amongst local people. The hunters were also blamed for preferring to employ people from other areas, despite the availability of young unemployed people in the local community. The community members also reported that the hunter took advantage of the HRDC's failure to recognise the people settling in the buffer zone and ignored their concerns. In In their turn, the hunter, as well as local authorities, blame the community for encroachment, poaching and contributing to the decline of the wildlife stock in the buffer zone and the safari.

\subsubsection{Rural District Council versus local community}

During the interviews, key stakeholder reported that the sporadic settlers moved and occupied the buffer zone. According to a HRDC representative, the buffer zone runs five kilometres parallel to the game fence. It was further stated that HRDC does not recognise the people settling within the buffer zone, and consequently the HRDC does not attend to their needs or complains about human-wildlife conflicts. The HRDC has conducted two mass demolition and eviction of the illegal settlers within the buffer zone in the past 15 years. However, people keep on moving back to the buffer zone when the HRDC officials leave the area. It was observed that the game fence was removed. In both subsequent phases of the research, authors observed cattle going into the game park for foraging and watering, and community members who participated in the FGDs confirmed that it is common that cattle go into the protected area. It was added that community members let them go and just go to bring them back at the end of the day. They also reported that it was difficult to collect the livestock before dusk, since the scouts are actively patrolling the park. There were reports of people having been beaten up by scouts if found in the game park.

Furthermore, both key informants and FGDs participants informed about community members engaging in illegal gold panning in the major rivers. HRDC officials complained about gold panner using chemicals (especially mercury) that are dangerous and kill animals that rely on the river systems downstream. The chemical that was reported as being commonly used in gold panning is mercury.

10 The CAMPFIRE committee with the stakeholders (including the community members) is in charge of selecting a hunter who is awarded a license to operate either for three or five years. 


\section{Discussion}

At least rhetorically, local people's inputs and participation in community conservation initiatives is valued by the state and the Department of National Parks and Wildlife (King, 2006). The Middle-Zambezi BR is supposed to balance sustainable conservation and livelihoods; however, we use the case of the Middle-Zambezi BR to critic the nexus between conservancy and economic resources that can generate sustainable livelihoods. The CAMPFIRE Programme had potential to facilitate community and stakeholder participation in the game reserve. However, the study shows that CAMPFIRE benefitted the Nyamakate community in the 1980s, before the implementation of the neo-liberal based structural adjustment programme, but it no longer benefits the community at present. CAMPFIRE involves the sale by rural authorities of the rights to access wildlife to entrepreneurs who in turn market safaris to hunters and eco-tourists (Frost and Bond, 2008). Some authors argue that the proceeds from the programme mainly benefited the Department of National Parks and Wildlife, HRDC and the CAMPFIRE Association more than the community (Hasler, 1999; Balint and Mashinya, 2006). Nevertheless, other authors (Frost and Bond, 2008) state that CAMPFIRE allowed community participation and benefits (although limited) from wildlife. The study participants reported that parks authorities used to distribute wild animals' meat as compensation for farmer's capital loss. Although the active involvement of the local community has always been limited, the scenario has worsened over time, as communities perceive that there is no longer any benefit from or engagement from the game reserve.

Currently, the community have lost power to effectively participate in the management of the safari area. The HRDC, the hunter and the Department of National Parks and Wildlife exclude the community from participating and accessing the park. Interviews with community leaders show that they are not allowed to participate in the selection of the hunter who operates in the safari area. Illegal access is the only way that community members "passively participate" and benefit from the protected area. With the low social capital, small groups (which can be defined as sub-cultures) perpetuated the encroachment into the park with an effort to benefit. This cannot be likened to Scott's (1985) "weapons of the weak" or any collective organisation; hence, the encroachment has been met with resistance from the HRDC, hunter and the Department of National Parks and Wildlife. In order to benefit and compensate for their losses due to destruction of livestock and fields by animals, they graze cattle in the park, illegally settle in the buffer zone, deforest and poach wildlife. There have been cases of wildlife targeted poisoning of water holes in areas close to Nyamakate. Political ecologists view marginalisation of the community to be responsible for natural resources degradation (Blaikie, 1985). A study in a farming area adjacent to Nyamakate shows that people hold negative attitudes towards wild animals that destroy their livestock and people retaliate by harming or killing those (Kupika et al., 2016).

The study demonstrates that independently of their socio-economic status, villagers of the Nyamakate area rely on natural resources services mainly for agriculture. The community is adapting to climate and structural changes through a number of entrepreneurial activities including, amongst 
others, the sale of carved wooden artefacts, sex trading, building contractors etc. People are adopting diverse livelihoods strategies to try to be less dependent on natural resources in response to climate change and economic hardships. The Nyamakate community does not have community eco-tourism initiatives although it has potential because of its location on a game park boundary. The shift from agricultural to other economic activities that are non-consumptive to the local biodiversity has been observed in other areas in Sub-Saharan Africa (Chimhowu and Hulme, 2006; Manyani, 2011). In cases where there is either high social capital or/and external support communities adopt eco-tourism enterprises in order to participate and benefit from biosphere reserves (Jones, 2005; Kimbu and Ngoasong, 2013). The ventures have minimal environmental disturbance, thus they biodiversity conservation is enhanced.

This study has demonstrated that Nyamakate community had low levels of financial, human and social capital. The low capital limit a community's investment into social enterprises. Scholars argue that to a large extent social capital is needed to ensure successful collective action in conservation and social enterprises (Pretty and Ward, 2001). Other scholars argue that social capital is a "slippery" concept it can work for or against conservation (Jones, 2005). Communities that have been generated as a result of resettlement programs, suffer from low social capital due to multi-culturalism, identity crises, lack of trust and socio-political issues (Barr, 2003; 2004). However, the evidence suggests that social capital in Nyamakate has potential to increase. Thus, social enterprises in the biosphere could take advantage of the social capital in distributing conservation responsibility and benefits amongst the community members. Such cooperation amongst social actors depends on reciprocity and proximity to one another (Sacchetti and Campbell, 2014). However, it should be noted that the locus of power rests with structural institutions and not the community. Institutional factors underlie the marginalisation of the poor in the Nyamakate area. The HRDC and Department of National Parks and Wildlife are state sanctioned structures and derive power from thereof. The act according to a capitalistic logic and they pursue the maximisation of their profits. Tour operators and hunters have been shown to take shortcuts on conservation and community engagement obligations in their bid to maximise profit in the short term (Batisse, 1997). Social capital becomes a useful tool to create community solidarity through horizontal social networks rather than vertical linkages. When there is community solidarity the Nyamakate community can bargain and push for participation and benefit from the BR.

\section{Conclusions}

This study has noted low levels of financial, human and social capital and limited social enterprises in the Middle-Zambezi BR. Yet, literature that has been reviewed here argues that human and social capital are key in community natural resources conservation. The institutions operating from the Nyamakate area do not promote community participation and direct benefits from the MiddleZambezi BR. The communities have been excluded from participating in the BR despite rhetoric of 
community participation. To this end, individuals within the community are using subtle and illegal methods to benefit from the natural resources as they struggle to survive. The study notes low levels of financial and social capital, which could be contributing to low levels of entrepreneurship and meaningful social enterprises in the Middle-Zambezi BR limiting social investment in community eco-tourism. If the Middle-Zambezi BR is to work towards sustainable development, the value of human and social capital in conservation shall be recognized and community participation shall be promoted through social enterprise. The community members show detailed knowledge of the changes in natural resources and policy would benefit by amalgamating this knowledge with more systematic monitoring of data on human population and natural resource stocks. Literature presented here has shown eco-tourism successes in promoting community development and biodiversity conservation through community and stakeholder participation. Besides the participatory rhetoric, the Middle-Zambezi BR is still managed as a protectorate, largely excluding rural community participation.

\section{References}

Balint, P.J. \& Mashinya, J. (2006). The decline of a model community-based conservation project: Governance, capacity, and devolution in Mahenye, Zimbabwe, Geoforum, 37(5): 805-815. DOI: https://doi.org/10.1016/j. geoforum.2005.01.011

Barr, A. (2003). Trust and expected trustworthiness: experimental evidence from Zimbabwean villages, The Economic Journal, 113(489): 614-630. DOI: https://doi.org/10.1111/1468-0297.t01-1-00150

Barr, A. (2004). Forging effective new communities: The evolution of civil society in Zimbabwean resettlement villages, World development, 32(10): 1753-1766.

Batisse, M. (1997). Biosphere reserves: a challenge for biodiversity conservation \& regional development, Environment: Science and Policy for Sustainable Development, 39(5): 6-33. DOI: https://doi.org/10.1080/00139159709603644

Blaikie, P. (1985). The political economy of soil erosion in developing countries. Harlow Essex, UK: The Longman development studies.

Chambers, R. (2011). Sustainable livelihoods: An opportunity for the World Commission on Environment and Development. Available at: https://opendocs.ids.ac.uk/opendocs/handle/123456789/873 [Accessed: 8 May 2016].

Child, B. (1993). Zimbabwe's CAMPFIRE programme: using the high value of wildlife recreation to revolutionize natural resource management in communal areas, The Commonwealth Forestry Review, 72(4): 284-296.

Chimhowu, A. \& Hulme, D. (2006). Livelihood dynamics in planned and spontaneous resettlement in Zimbabwe: converging and vulnerable, World Development, 34(4): 728-750. DOI: https://doi.org/10.1016/j. worlddev.2005.08.011

Edge, S. \& McAllister, M.L. (2009). Place-based local governance and sustainable communities: lessons from Canadian biosphere reserves, Journal of Environmental Planning and Management, 52(3): 279-295. DOI: https://doi. org/10.1080/09640560802703058

Frost, P.G. \& Bond, I. (2008). The CAMPFIRE programme in Zimbabwe: payments for wildlife services, Ecological Economics, 65(4): 776-787.

Getz, W.M., Fortmann, L., Cumming, D., Du Toit, J., Hilty, J., Martin, R., Murphree, M., Owen-Smith, N., Starfield, A.M. \& Westphal, M.I. (1999). Sustaining natural and human capital: villagers and scientists, Science, 283(5409): 1855-1856. DOI: https://doi.org/10.1126/science.283.5409.1855 
Guerry, A.D., Polasky, S., Lubchenco, J., Chaplin-Kramer, R., Daily, G.C., Griffin, R., Ruckelshaus, M., Bateman, I.J., Duraiappah, A., Elmqvist, T., Feldman, M.W., Folke, C., Hoekstra, J., Kareiva, P. M., Keeler, B., Li, S., McKenzie, E., Ouyang, Z., Reyers, B., Ricketts, T.H., Rockström, J., Tallis, H. \& Vira, B. (2015). Natural capital and ecosystem services informing decisions: From promise to practice, Proceedings of the National Academy of Sciences, 112(24): 7348-7355. DOI: https://doi.org/10.1073/pnas.1503751112

Hasler, R. (1999). An overview of the social, ecological and economic achievements and challenges of Zimbabwe's CAMPFIRE Programme. London: IIED.

Ishwaran, N., Persic, A. \& Tri, N.H. (2008). Concept and practice: the case of UNESCO biosphere reserves, International Journal of Environment and Sustainable Development, 7(2): 118-131. DOI: https://doi.org/10.1504/ IJESD.2008.018358

Johnson, P.A. (2010). Realizing rural community-based tourism development: Prospects for social economy enterprises, Journal of rural and community development, 5(1): 150-162.

Jones, S. (2005). Community-based ecotourism: The significance of social capital, Annals of Tourism Research, 32(2): 303324. DOI: https://doi.org/10.1016/j.annals.2004.06.007

Jones, B. \& Weaver, C. (2009). CBNRM in Namibia: growth, trends, lessons and constraints. In: H. Suich, B. Child \& A. Spenceley (Eds.), Evolution and innovation in wildlife conservation: parks and game ranches to transfrontier conservation areas. London - Sterling, VA: Earthscan, pp. 223-242.

Kimbu, A. (2013). Political instability in the Central African sub-region and its impact on the image of Cameroon as a tourism destination. In: W.C. Gartner \& T. Mihalič (Eds.), Tourism and Developments: Issues and Challenges. New York: Nova Science Publishers Inc., pp. 335-364.

Kimbu, A.N. \& Ngoasong, M.Z. (2013). Centralised decentralisation of tourism development: a network perspective, Annals of Tourism Research, 40: 235-259. DOI: https://doi.org/10.1016/j.annals.2012.09.005

Kimbu, A.N. \& Ngoasong, M.Z. (2016). Women as vectors of social entrepreneurship, Annals of Tourism Research, 60: 63-79. DOI: https://doi.org/10.1016/j.annals.2016.06.002

Kupika, O.L., Gwatsvaira, F., Kuvawoga, P.T., Muposhi, V.K. \& Mbereko, A. (2016). Assessment of livestock depredation by lion and spotted hyena in farming areas adjacent to Hurungwe and Charara Safari Areas, northern Zimbabwe, Annals of Social and Behavioural Sciences, 2: 7-22.

Le Bel, S., La Grange, M. \& Czudek, R. (2016). Managing Human-Elephant Conflict in Zimbabwe: A Boundary Perspective Rather Than a Problematic Species Issue. In: F.M. Angelici (Ed.), Problematic Wildlife. A CrossDisciplinary Approach. Berlin: Springer, pp. 123-142.

Lehtonen, M. (2004). The environmental-social interface of sustainable development: capabilities, social capital, institutions, Ecological Economics, 49(2): 199-214. DOI: https://doi.org/10.1016/j.ecolecon.2004.03.019

Manyani, C.R. (2011). The peasantry during a decade of economic decline in Zimbabwe. Research Paper. The Hague, Netherlands: International Institute on Social Studies.

Mbereko, A. (2016). Changing spirituality and natural resources base: Implications for common natural resources management in the mid-Zambezi valley, Nature and Faune, 30(2): 35-39.

Mbereko, A., Scott, D. \& Kupika, O.L. (2015). First generation land reform in Zimbabwe: historical and institutional dynamics informing household's vulnerability in the Nyamakate Resettlement community, Journal of Sustainable Development in Africa, 17(3): 21-38.

McNeely, J.A. (1994). Protected areas for the 21st century: working to provide benefits to society, Biodiversity \& Conservation, 3(5): 390-405. DOI: https://doi.org/10.1007/BF00057797

Naughton-Treves, L., Holland, M.B. \& Brandon, K. (2005). The role of protected areas in conserving biodiversity and sustaining local livelihoods, Annual Review of Environment and Resources, 30: 219-252. DOI: https://doi. org/10.1146/annurev.energy.30.050504.164507

Ogutu, Z. (2002). The impact of ecotourism on livelihood and natural resource management in Eselenkei, Amboseli ecosystem, Kenya, Land Degradation \& Development, 13(3): 251-256. DOI: https://doi.org/10.1002/ldr.502 
Ostrom, E. (2015). Governing the commons. Cambridge: Cambridge University Press. DOI: https://doi.org/10.1017/ CBO9781316423936

Pahl-Wostl, C. (2007). The implications of complexity for integrated resources management, Environmental Modelling \& Software, 22(5): 561-569. DOI: https://doi.org/10.1016/j.envsoft.2005.12.024

Pool-Stanvliet, R. \& Clusener-Godt, M. (Eds.) (2013). AfriIMAB - Biosphere Reserves in Sub-Saharan Africa: Showcasing Sustainable Development. Published by the Department of Environmental Affairs Directorate: Protected Areas Planning, Legislation, Compliance and Monitoring, Pretoria, South Africa and UNESCO Division of Ecological and Earth Sciences, Paris. Available at: http://unesdoc.unesco.org/images/0022/002269/226919E.pdf [Accessed: February 2017].

Pretty, J.N. (1995). Participatory learning for sustainable agriculture, World Development, 23(8): 1247-1263. DOI: https://doi.org/10.1016/0305-750X(95)00046-F

Pretty, J. \& Ward, H. (2001). Social capital and the environment, World Development, 29(2): 209-227. DOI: https://doi. org/10.1016/S0305-750X(00)00098-X

Rao, K.S., Nautiyal, S., Maikhuri, R.K. \& Saxena, K.G. (2003). Local peoples' knowledge, aptitude and perceptions of planning and management issues in Nanda Devi Biosphere Reserve, India, Environmental management, 31(2): 0168-0181. DOI: https://doi.org/10.1007/s00267-002-2830-4

Roe, D. \& Elliott, J. (2006). Pro-poor conservation: the elusive win-win for conservation and poverty reduction, Policy Matters, 14(03).

Sacchetti, S. \& Campbell, C. (2014). Creating space for communities: social enterprise and the bright side of social capital, Journal of Entrepreneurial and Organizational Diversity, 3(2): 32-48. DOI: https://doi.org/10.5947/ jeod.2014.012

Salafsky, N. \& Wollenberg, E. (2000). Linking livelihoods and conservation: a conceptual framework and scale for assessing the integration of human needs and biodiversity, World development, 28(8): 1421-1438. DOI: https:// doi.org/10.1016/S0305-750X(00)00031-0

Schliep, R., Bertzky, M., Hirschnitz, M. \& Stoll-Kleemann, S. (2008). Changing Climate in Protected Areas?: Risk Perception of Climate Change by Biosphere Reserve Managers, GAIA-Ecological Perspectives for Science and Society, 17(1): 116-124. DOI: https://doi.org/10.14512/gaia.17.S1.9

Scoones, I. (1998). Sustainable rural livelihoods: a framework for analysis, IDS Working Paper, 72. Brighton, UK: Institute of Development Studies.

Scoones, I. (2015). Sustainable livelihoods and rural development. Practical Action Publishing. DOI: https://doi. org/10.3362/9781780448749

Scott, J.C. (1985). Weapons of the weak: Everyday forms of peasant resistance, New Haven: Yale University Press.

Stoll-Kleemann, S., De la Vega-Leinert, A. \& Schultz, L. (2010). The role of community participation in the effectiveness of UNESCO Biosphere Reserve management: evidence and reflections from two parallel global surveys. Environmental Conservation, 37(03): 227-238. DOI: https://doi.org/10.1017/S037689291000038X

Taylor, P.L. (2010). Conservation, community, and culture? New organizational challenges of community forest concessions in the Maya Biosphere Reserve of Guatemala, Journal of Rural Studies, 26(2): 173-184. DOI: https:// doi.org/10.1016/j.jrurstud.2009.09.006

Timko, J.A. \& Innes, J.L. (2009). Evaluating ecological integrity in national parks: Case studies from Canada and South Africa. Biological Conservation, 142(3): 676-688. DOI: https://doi.org/10.1017/S037689291000038X

Wearing, S. \& McDonald, M. (2002). The development of community-based tourism: Re-thinking the relationship between tour operators and development agents as intermediaries in rural and isolated area communities, Journal of sustainable tourism, 10(3): 191-206. DOI: https://doi.org/10.1080/09669580208667162 